\title{
Editorial: What Economics Needs to Become
}

\author{
WENDY HARCOURT
}

In a volume on culture and identity it might seem at first somewhat puzzling to have the third issue devoted to 'Beyond Economics'. Following on from issues on 'sexuality and development', 'power, movements, change' and anticipating 'xenophobia, culture and identity' the topic might appear incongruent. When the editorial board was finalizing the themes for Volume 52 in October 2008 the financial crisis in the run up to the United States elections was just hitting the news. What had actually been slated as the third issue was the culture of markets as a way of life that pervaded much of the mainstream development policy. We originally had thought to unpack the unbridled reliance on markets. However, history beat us to it and in our conversations reflecting on the profound shake up of the financial collapse wrought on economic wisdom, it was clear that it was not the concept of markets that needed to be revisited but economics itself. It was time to challenge very seriously within the development community the economic principles driving the interlocked crises of food, climate and finance, as well as the equally intertwined though far less visible global crisis of care.

The journal issue has taken up the challenge with three sets of articles. The first addresses the financial and economic crises as well as food, climate and care crises by looking at what urgently needs to change in economic thinking and policy. Though criticizing the current greed of global capitalism and its dire impact on peoples' livelihoods, the environment and social relations the articles go beyond a diagnosis of problem. They look at what economics needs to become. Much of what they say is not entirely new to Development readers familiar with an editorial line that over the years has warned of the systemic faults in economic thinking that are not being addressed in development policy. Many issues of Development, beginning in the 1970s with the promotion of the new international economic order and human development have warned that economic development policy that fails to take into account people and the environment can only lead to increasing inequalities, poverty and devastation of the environment. What is new is that these writers are economists who are being self-reflective on the profession itself. The severity of the crises demands that the economic leaders (whether in academe or in policy) go beyond given economic beliefs and culture to change radically economic policies. It is imperative to drop neo-liberal belief in the market and recognize that new value systems, new forms of accountability, new forms of democracy are needed; ones responding to today's realities and not harking back to 
old ideologies, of either right or left. Particularly challenging is how to bring in ordinary peoples' needs rather than market needs as central to economics. In this process the question is what type of economics can redress the gender imbalances and geopolitical constraints, which perpetuate the deep and pervasive inequalities that rob the majority of the world's lives of dignity and push the powerful minority along a fast and destructive pace of greed. There are answers given in the articles, from strengthening the multilateral system to introducing radically different monetary policy to ensuring full employment. Not all the authors are convinced that the systemic changes are going to be made easily, given the breadth of the crises and the entrenched ways of global political and economic institutions.

The second set of articles takes up what this rethinking of the culture of economics means for development models, which are so solidly based on the assumption of economic growth, trade and aid. The authors tackle this question with a solid focus on the livelihoods and rights of poor women and men, and the environment as the true focus for development. They argue how it is critical to move away from aid dependency and embrace principles of environmental and humancentred development that confronts the poverty that invades most of the world, North and South.

A strong message of the issue is to respect and take into account the livelihoods and rights of productive work of all kinds, and take far more seriously the major social and economic impact of climate change. Most of all in the wake of the current crises valuing care work needs to become a visible, crucial development strategy. The care crisis even in the most liberal of circles is rarely spoken about largely due to the gendered nature of the work. The role of caring, mostly undertaken by women, is too often just assumed, even if it is mostly invisible in official accounts and policy. Care work is vital for the survival of societies and economies. Currently it is work being carried out at the cost of the rights and health of women, as their capacity to care is being stretched to the limits in today's stressed and unequal society. Development policy needs to take into account 278 production and reproduction in relation to gender relations, social and cultural norms, as well as national and global economic trends. In going beyond economics, care needs to be factored into new development analysis and policies, if we are to find sustaining ways for societies to survive the current crises.

In the last section the articles look to the future as authors envisage a new world order based on ecological, gender and social justice. These articles though perhaps offering more hope than the earlier sections' responses to the interlocked crises are not created out of fanciful utopian dreams. Instead they are based on the experiences and realities of ordinary lives, mindful of what has failed in a wealth and consumerist led society, and what has worked on the margins and peripheries of global capitalism. The vision is founded on what is possible on the small scale, and what exists outside global capitalism. The articles point to how all of us could move to a much more sustainable, harmonious, liveable and just world orders. Indeed they set out how we could create a new form of culture based on a different understanding of how economics works interlinked and informing ecological, social and political spheres.

Sadly this issue also commemorates and mourns the sudden deaths of two friends to the journal in the last months. Smitu Kothari was a much loved and respected intellectual activist from India and a valued member of the editorial board who contributed greatly to the work of Society for International Development (SID), particularly in South Asia. The second loss is the champion of Pan Africanism - Tajudeen Abdul Raheem, whose untimely death shocked the development world profoundly. He too was a great friend of the journal and the work of the East African programme. I am proud that we have published articles of both of them and their insights have helped shape the enduring message of the journal for peace, economic and social justice. In their different ways they carried a vision of justice based on a deep understanding of humanity and the frailties of economic and political processes. They both inspired the huge networks they engaged in to work collectively and honestly towards challenging prejudice, and transforming economies and societies. The death 
of Taj has lead to a huge number of memorials in his honour in all forms of media and is turning into a celebration of Pan Africanism on the continent of Africa. ${ }^{1}$ They were global citizens, family men and dear friends, loved and respected by many, ${ }^{2}$ remembered for their smiles and joy as well as wisdom they gave us in how to move towards a better world.

\section{Notes}

1 The popular list serve Pambazuka News, Pan African Voices for Freedom and Justice, is fielding all the comments and discussions. See http://www.pambazuka.org/en/category/Tajudeen. Firoze Manji, in Pambazuka News 436 on 4 June, as the editorial goes to press, reports that 'tributes to Tajudeen Abdul Raheem, pan-Africanist, fighter, comrade and friend to so many, continue to pour in at Pambazuka News. Since last week, we have received some 60 tributes bringing the total to more than 250.' http://www.pambazuka.org/en/category/obituary/.

2 Smitu's friends from around the world have sent many tributes to Smitu on a website set up to celebrate and remember Smitu. See http://celebrating-smitu.org/. 